\title{
Assessing a Body Shape Index and Waist to Height Ratio as a Risk Predictor for Insulin Resistance and Metabolic Syndrome among Korean Adults
}

Kyung-A Shin

Department of Clinical Laboratory Science, Shinsung University, Dangjin, Korea

\section{한국 성인의 인슐린저항성 및 대사증후군 위험 예측인자로서 체형지수와 허리둘레/신장 비율의 효용성}

\section{신경아}

\author{
신성대학교 임상병리과
}

\begin{abstract}
The WHtR (waist to height ratio) and ABSI (a body shape index) are indicators that reflect abdominal obesity. This study examined the insulin resistance and metabolic syndrome prediction ability of ABSI and WHtR. In this study, 4,395 people aged 20 years or older, who underwent physical examinations at a General Hospital in Gyeonggi-do from January 2017 to September 2017 were assessed on a cross section survey. Metabolic syndrome was defined according to the criteria of the AHA/NHLBI. Insulin resistance was judged to be insulin resistance when the HOMA-IR value was 3.0 or more. Both men and women showed a stronger correlation between WHtR and the metabolic risk factors than ABSI. The AUC value of WHtR and ABSI was 0.849 and 0.676 , respectively $(p<0.001)$. The AUC value of WHtR and ABSI for predicting insulin resistance was 0.818 and 0.641 , respectively $(p<0.001)$. In conclusion, the ABSI has low predictive power of insulin resistance and metabolic syndrome whereas the WHtR has good predictive power for metabolic syndrome and insulin resistance.
\end{abstract}

Key words: A body shape index, Waist to height ratio, Insulin resistance, Metabolic syndrome

This is an Open Access article distributed under the terms of the Creative Commons Attribution Non-Commercial Licens (http://creativecommons.org/licenses/by-nc/4.0) which permits unrestricted non-commercial use, distribution, and reproduction in any medium, provided the original work is properly cited.

Copyright (C) 2018 The Korean Society for Clinical Laboratory Science. All rights reserved.
Corresponding author: Kyung-A Shin Department of Clinical Laboratory Science, Shinsung University, 1 Daehak-ro, Jeongmi-myeon, Dangjin 31801, Korea Tel: 82-41-350-1408 Fax: 82-41-350-1355

E-mail:mobitz2@hanmail.net

Received: December 26, 2017 Revised $1^{\text {st. }}$ January 15, 2018 Revised $2^{\text {nd }}:$ January 25,2018 Accepted: January 25, 2018

\section{서 론}

대사증후군(metabolic syndrome)은 2013년 우리나라 인 구 중 $35.3 \%$ 의 유병률을 보이는 만성질환으로 심혈관질환의 위 엄 증가와 관련이 있다[1,2]. 대사증후군은 고혈당, 고혈압, 이 상지질혈증, 복부비만 및 인슐린저항성의 대사장애가 한 개인 에게 동반되어 나타나는 것으로 정의된다[3]. 특히 비만은 인슐 린저항성과 대사증후군의 가장 강력한 예측 인자이며[4], 당뇨
병 및 심혈관질환의 위험요인이다[5]. 최근 식습관 및 생활방식 의 서구화로 비만 인구는 급격히 증가하고 있으며, 우리나라의 국민건강영양조사에 따르면 2014년 비만 유병률은 31.5\%로 조사되었다[1].

현재 비만을 평가하기 위해 일반적으로 사용되는 비만관리 지표는 체질량지수(body mass index, BMI), 체지방률(body fat percentage, $\mathrm{BF} \%$ ), 허리둘레, 허리둘레/엉덩이둘레 비율 (waist to hip ratio, WHR) 등이 사용되고 있으며, 질병발생 및 
조기사망률을 예측하는 비만지표로 $\mathrm{WHO}$ 에서는 체질량지수 와 허리둘레를 언급하였다[6,7]. 체질량지수는 오랫동안 비만 관리 예측 인자로 인식되어 왔으나[4], 지방과 근육량의 분별력 이 부족하고 체내 지방 분포의 차이를 명확하게 구분하는데 한 계가 있다[8-10]. 전향적 코호트 연구를 메타 분석한 결과 허리 둘레가 $1 \mathrm{~cm}, \mathrm{WHR}$ 이 0.01 증가함에 따라 심혈관질환 위험은 각각 $2 \%, 5 \%$ 증가하는 것으로 보고되며[11], 이러한 중심성 비 만을 보다 정확하게 측정하기 위해 허리둘레가 체질량지수의 한계를 극복하고자 제안되었다[4]. 그러나 허리둘레만으로 비 만을 평가할 경우 같은 허리둘레를 가졌더라도 큰 키에 비해 작 은 키의 사람에게서 심혈관질환의 위험이 높을 수 있다[12]. 그 러므로 몇몇 연구에서는 허리둘레보다 심혈관질환 위험을 더 잘 예측하는 또 다른 복부비만 지표로 허리둘레/신장 비율 (waist to height ratio, WHtR)이 제시되었다[13-15]. 신장과 심혈관질환 위험요인간에는 역상관 관계를 보이며, 이로 인해 허리둘레를 신장으로 교정한 경우 심혈관질환 위험을 더 잘 예 측할 수 있다고 보고된다[16]. 또한 허리둘레를 신장으로 교정 함으로써 인종, 성별, 연령에 따라 공통적으로 적용할 수 있다 [6]. Lin 등[17]은 대만여성을 대상으로 WHtR이 허리둘레, WHR 및 체질량지수보다 심장질환의 위험 인자를 예측하는 데 더 좋은 지표라고 보고하였다. 국내 연구로는 Kim 등[6]이 당뇨 병 전기 환자를 대상으로 $\mathrm{WHtR}$ 이 대사증후군을 예측하는 지표 로써 유용함을 평가하였다.

한편 Krakauer 등[18]은 최근 복부비만의 선택적 지표로써 신장 및 허리둘레와 체질량지수를 동시에 반영하는 체형지수(a body shape index, ABSI)를 개발하였으며, ABSI가 말초지방 보다 내장지방과 더 관련 있다고 주장하였다. 또한, $\mathrm{ABSI}$ 는 체 지방량과 양의 상관관계를 보이며, 제지방량(fat free mass)과 는 음의 상관관계가 관찰되어 잠재적으로 대사장애의 좋은 예 측인자가 될 수 있다고 보고된다[18]. 그러나 ABSI와 건강위험 사이의 관계에 대한 결과들은 아직까지 논란의 여지가 있다. Bozorgmanesh 등[19]은 ABSI가 심혈관질환의 위험요인 증가 와 관련이 있다고 보고하였으나, 이와는 대조적으로 Maessen 등[20]은 중국인을 대상으로 15년간 추적 조사한 결과 ABSI가 심혈관질환 위험요인과 당뇨병을 예측하는 신뢰할만한 측정 지 표가 아니라는 사실을 입증하였다. 이와 같이 새로운 건강지표 들과 심혈관계와의 관계 등에 대해 많은 연구가 이루어지고 있 지만 대사증후군을 예측하는 지표로 아직까지 명확하게 제시된 것은 없다. 또한, $\mathrm{WHtR}$ 과 $\mathrm{ABSI}$ 는 인슐린저항성과 대사증후군 의 좋은 예측 인자가 될 수 있을 것으로 생각되지만, 서양인을 대 상으로 복부비만을 예측하는 지표로 개발되어 다른 인종에서도
그 적절성에 대한 평가의 필요성이 요구된다. 그러나 국내 일반 인을 대상으로 성별에 따라 기존 지표들과 WHtR 및 $\mathrm{ABSI}$ 를 비 교하여 대사증후군 발생을 예측하는데 적합한 지표인지를 평가 한 연구는 보고된 예가 드물다.

따라서 이 연구에서는 일반 성인을 대상으로 허리둘레, WHR과 같은 복부비만을 반영하는 다른 임상적 지표와 WHtR 및 $\mathrm{ABSI}$ 를 비교하여 대사증후군 및 인슐린저항성의 예측 지표 로써 WHtR 및 ABSI의 유용성을 확인하고자 하였다.

\section{대상 및 방법}

\section{1. 연구 대상}

이 연구는 2017년 1월부터 2017년 9월까지 경기도 소재 일 개 종합병원의 종합검진센터를 방문하여 건강진단을 받은 20 세 이상 성인 남녀를 대상으로 하였다. 전체 대상자인 17,907명 중 고혈압이나 당뇨병 병력이 있거나, 진단을 받고 현재 해당 약 제를 투여하는 경우, 지질 강하제를 복용하는 경우, 자료에 결측 치가 있는 경우에 해당하는 13,512 명을 제외한 4,395명을 최 종 연구 대상자로 선정하였다. 총 대상자 중 남성은 2,349명, 여 성은 2,046 명이었다. 자기기입식 설문지를 바탕으로 고혈압, 당뇨병의 병력 및 약물 복용력에 대한 자료를 확인하였으며, 이 연구는 경기지역 소재의 종합병원에서 기관연구윤리심의위원 회(institutional review board, IRB)의 심의를 받아 승인을 얻 은 후 연구를 수행하였다(IRB No: D-1207-011-0154).

\section{2. 연구방법}

\section{1) 인체계측 및 혈압측정}

임피던스 측정법을 적용한 체성분 분석기 Inbody 720 (Biospace Co., Seoul, Korea)을 이용하여 신장 및 체중을 측정 하였고, $\mathrm{BMI}$ 는 체중 $(\mathrm{kg})$ 을 신장 $(\mathrm{m})$ 의 제곱으로 나누어 계산하 였다. 허리둘레 측정은 숨을 내쉰 상태에서 $\mathrm{WHO}$ 의 권고방법 인 늑골 하단부와 장골능 상부의 중간 부위를 수평으로 측정하 였다. 엉덩이 둘레는 대퇴골 대전자의 가장 넓은 부위를 줄자로 재었다. WHR은 허리둘레 $(\mathrm{cm}) /$ 엉덩이둘레 $(\mathrm{cm})$ 로 구하였으 며, WHtR은 허리둘레 $(\mathrm{cm}) /$ 신장 $(\mathrm{cm})$ 으로 계산하였다. ABSI는 신장, 체중, 허리둘레, $\mathrm{BMI}$ 값을 이용하여 다음 공식으로 산출 하였다[18].

$$
\text { ABSI }=\frac{\text { Waist circum ference }}{\text { BMI }^{2 / 3} \times \text { Height }^{1 / 2}}
$$


수축기와 이완기 혈압은 mercury sphygmomanometer (Baumanometer, WA, NY)로 측정하였으며, 안정 상태에서 2 분 간격으로 2 회 측정하여 평균치를 구하였다.

\section{2) 진단기준 및 혈액분석}

대사증후군은 AHA/NHLBI (American Heart Association/ National Heart, Lung, and Blood Institute)의 진단기준에 따 라 정의하였다[21]. 대사증후군 각 구성요소는 수축기 혈압 $\geq$ $130 \mathrm{mmHg}$ 또는 이완기 혈압 $\geq 85 \mathrm{mmHg}$ 인 경우, 공복혈당 $\geq 100 \mathrm{mg} / \mathrm{dL}$ 인 경우, 혈중 중성지방 $\geq 150 \mathrm{mg} / \mathrm{dL}$, 혈중 $\mathrm{HDL}$ (high density lipoprotein)-콜레스테롤은 남성 $<40 \mathrm{mg} / \mathrm{dL}$, 여성 $<50 \mathrm{mg} / \mathrm{dL}$ 인 경우이며, 허리둘레는 아시아-태평양 기준 인 남성 $\geq 90 \mathrm{~cm}$, 여성 $\geq 80 \mathrm{~cm}$ 을 따랐다. 위의 5 가지 항목 중 3 가지 이상 소견을 보이는 경우 대사증후군으로 진단하였다 [22]. 혈액검사는 12시간 이상 금식 후 정중전완정맥(median antebrachial vein)에서 채혈하여 혈청으로 분석하였다. 측정 항목으로 총콜레스테롤, 중성지방, $\mathrm{HDL}$-콜레스테롤, $\mathrm{LDL}$-콜 레스테롤(low density lipoprotein-cholesterol), 공복혈당, 요산, 고감도 C-반응단백(high sensitivity C-reactive protein,
hs-CRP)은 TBA-200FR NEO (Toshiba, Tokyo, Japan) 장비 로 측정하였다. 당화혈색소(hemoglobin A1c, HbA1c)는 고 속액체크로마토그래피법(high performance liquid chromatography, HPLC)의 원리로 Variant II (Bio Rad, CA, USA) 장비 로 측정하였다. 인슐린은 전기화학발광면역측정법(electrochemiluminescence immunoassay, ECLIA)의 원리로 Roche Modular Analytics E170 (Roche, Mannheim, Germany) 장 비를 사용하여 검사하였다. 인슐린저항성의 간접적인 평가 지 표로서 인슐린저항성 지수(homeostasis model assessmentinsulin resistance, HOMA-IR)를 적용하였으며, 공복 혈당과 인슐린 수치를 이용하여 [공복 인슐린 농도 $(\mu \mathrm{IU} / \mathrm{mL}) \times$ 공복 혈 당 $(\mathrm{mg} / \mathrm{dL}) / 405$ ] 공식으로 계산하였다[23]. 인슐린저항성 평가 는 HOMA-IR값이 3.0 이상인 경우 인슐린저항성이 있는 것으 로 판정하였다[24].

\section{3. 통계분석}

이 연구의 통계분석은 IBM SPSS Statistics 24.0 (IBM, NY, USA) 통계 프로그램을 사용하여 수집된 자료를 통계 처리하였 다. 모든 자료는 평균과 표준편차로 표시하였으며, 범주형 변수

Table 1. The general characteristics of study population

\begin{tabular}{|c|c|c|c|c|}
\hline Characteristics & Men $(N=2,349)$ & Women $(\mathrm{N}=2,046)$ & $p$-value & Total $(\mathrm{N}=4,395)$ \\
\hline Age (yr) & $49.37 \pm 10.94$ & $49.02 \pm 12.04$ & 0.314 & $49.21 \pm 11.46$ \\
\hline Height $(\mathrm{cm})$ & $170.90 \pm 6.22$ & $157.80 \pm 5.93$ & $<0.001$ & $164.80 \pm 8.93$ \\
\hline Weight (kg) & $72.34 \pm 10.04$ & $56.69 \pm 7.91$ & $<0.001$ & $65.05 \pm 12.00$ \\
\hline BMI $\left(\mathrm{kg} / \mathrm{m}^{2}\right)$ & $24.83 \pm 5.59$ & $23.01 \pm 7.90$ & $<0.001$ & $23.99 \pm 6.83$ \\
\hline Waist circumference $(\mathrm{cm})$ & $84.50 \pm 7.71$ & $74.37 \pm 8.05$ & $<0.001$ & $79.78 \pm 9.35$ \\
\hline Hip circumference $(\mathrm{cm})$ & $95.11 \pm 5.53$ & $91.31 \pm 5.44$ & $<0.001$ & $93.34 \pm 5.80$ \\
\hline WHR & $0.88 \pm 0.05$ & $0.81 \pm 0.06$ & $<0.001$ & $0.85 \pm 0.06$ \\
\hline WHtR & $0.49 \pm 0.04$ & $0.47 \pm 0.05$ & $<0.001$ & $0.48 \pm 0.05$ \\
\hline ABSI & $0.0763 \pm 0.004$ & $0.0739 \pm 0.007$ & $<0.001$ & $0.0752 \pm 0.006$ \\
\hline Systolic BP (mmHg) & $114.21 \pm 13.36$ & $106.98 \pm 15.27$ & $<0.001$ & $110.85 \pm 14.73$ \\
\hline Diastolic BP (mmHg) & $73.36 \pm 9.66$ & $67.58 \pm 9.99$ & $<0.001$ & $70.67 \pm 10.23$ \\
\hline Total cholesterol (mg/dL) & $197.07 \pm 35.41$ & $194.42 \pm 35.13$ & 0.013 & $195.83 \pm 35.33$ \\
\hline $\mathrm{HDL}-\mathrm{C}(\mathrm{mg} / \mathrm{dL})$ & $51.64 \pm 12.30$ & $62.04 \pm 14.15$ & $<0.001$ & $56.49 \pm 14.17$ \\
\hline $\mathrm{LDL}-\mathrm{C}(\mathrm{mg} / \mathrm{dL})$ & $123.84 \pm 31.96$ & $117.48 \pm 32.28$ & $<0.001$ & $120.88 \pm 32.26$ \\
\hline Triglyceride (mg/dL) & $145.74 \pm 95.57$ & $93.46 \pm 59.85$ & $<0.001$ & $120.40 \pm 85.02$ \\
\hline Fasting glucose (mg/dL) & $94.61 \pm 22.59$ & $88.87 \pm 15.61$ & $<0.001$ & $91.94 \pm 19.86$ \\
\hline $\mathrm{HbA} 1 \mathrm{c}(\%)$ & $5.74 \pm 0.88$ & $5.57 \pm 0.60$ & $<0.001$ & $5.66 \pm 0.77$ \\
\hline Insulin (uU/mL) & $5.19 \pm 3.24$ & $4.51 \pm 2.79$ & $<0.001$ & $4.87 \pm 3.05$ \\
\hline HOMA-IR & $1.24 \pm 0.92$ & $1.01 \pm 0.74$ & $<0.001$ & $1.14 \pm 0.84$ \\
\hline Uric acid (mg/dL) & $5.93 \pm 1.29$ & $4.19 \pm 0.96$ & $<0.001$ & $5.12 \pm 1.44$ \\
\hline $\mathrm{hs}-\mathrm{CRP}(\mathrm{mg} / \mathrm{dL})$ & $0.20 \pm 0.67$ & $0.14 \pm 0.35$ & $<0.001$ & $0.17 \pm 0.55$ \\
\hline MetS (\%) & $318(13.5)$ & $179(8.7)$ & $<0.001$ & $497(11.3)$ \\
\hline IR (\%) & $111(4.7)$ & $49(2.4)$ & $<0.001$ & $160(3.6)$ \\
\hline
\end{tabular}

Calculated by independent t-test and chi-square test.

Values are presented as mean \pm SD and number (\%).

Abbreviations: BMI, body mass index; WHR, waist hip ratio; WHtR, waist height ratio; ABSI, a body shape index; BP, blood pressure; HDL-C, high density lipoprotein cholesterol; LDL-C, low density lipoprotein cholesterol; HbA1c, hemoglobin A1c; HOMA-IR, homeostasis model assessment-insulin resistance; hs-CRP, high sensitivity C-reactive protein; MetS, metabolic syndrome; IR, insulin resistance. 
에 대해서는 \%로 나타냈다. 성별에 따른 인체측정학적 및 생화 학적 측정변인의 차이, 대사증후군 및 인슐린저항성 유무에 따 른 WHtR과 ABSI의 차이를 확인하기 위해 독립표본 $t$ 검정 (independent sample $t$-test)을 시행하였다. 또한 대사증후군 위험요인의 개수에 따른 WHtR과 ABSI의 차이를 확인하기 위 해 일원분산분석(one way analysis of variance, ANOVA)을 실 시하였다. 일원분산분석 결과 유의한 차이가 있을 경우 사후검 증(post-hoc test, multiple comparison)을 실시하였으며, bonferroni 검증방법을 적용하였다. WHtR 및 $\mathrm{ABSI}$ 와 대사적 위험인자간의 상호연관성에 대해 검증하고자 상관관계분석 (correlation analysis)을 시행하였다. 또한 ROC (receiver operating characteristic curve, ROC curve)분석을 이용하여 허리둘레, WHR, WHtR과 ABSI가 대사증후군 및 인슐린저항 성 예측을 위한 정확한 지표인지를 알아보기 위해 면적을 산출 하여 비교하였다. X축은 1-특이도, Y축을 민감도로 하여 곡선 의 면적은 0 과 1 사이의 값을 가지며, 곡선 아래의 면적(area under the curve, AUC)이 0.7 이상인 경우 대사증후군 및 인슐
린저항성을 예측하는데 중등도 이상의 정확성을 반영하는 것으 로 간주하였다[25]. 대사증후군 및 인슐린저항성을 진단하기 위한 허리둘레, $\mathrm{WHR}, \mathrm{WHtR}$ 와 ABSI의 적정 기준치(optimum cut-off values)를 판단하기 위해 민감도(sensitivity)와 특이도 (specificity)로 평가하였고 그 합이 가장 큰 지점을 적정 기준치 로 채택하였다. 이 연구의 모든 통계적 유의수준은 $p$ 값이 0.05 미만일 때 통계적으로 유의한 것으로 판정하였다.

\section{결 과}

\section{1. 성별에 따른 대상자의 인체측정학적 및 생화학적 변인의 차이}

성별을 나누어 연구 대상자의 인체측정 변인 및 생화학적 변 인의 차이를 확인한 결과는 Table 1과 같다. 이 연구 대상자의 평균 연령은 $49.2 \pm 11.5$ 세 이며, 성별에 따른 연령은 차이가 없 었다. 인체측정학적 변인인 신장, 체중, BMI, 어리둘레, 엉덩이 둘레, WHR, WHtR, ABSI의 수준은 성별에 따라 유의하게 차이

Table 2. Differences between WHtR and ABSI with or without MetS and IR

\begin{tabular}{ccccc}
\hline & MetS & Non-MetS & IR & Non-IR \\
\hline WHtR & $0.54 \pm 0.04^{* \star}$ & $0.47 \pm 0.04$ & $0.54 \pm 0.05^{\star *}$ & $0.48 \pm 0.05$ \\
ABSI & $0.0776 \pm 0.004^{\star *}$ & $0.0749 \pm 0.006$ & $0.0772 \pm 0.005^{\star *}$ & $0.0751 \pm 0.006$ \\
\hline
\end{tabular}

Calculated by independent t-test.

Values are presented as mean \pm SD.

${ }^{* *} p<0.001$.

Abbreviations: WHtR, waist height ratio; $A B S I$, a body shape index; MetS, metabolic syndrome; IR, insulin resistance.

Table 3. The correlation of WHtR and ABSI with metabolic risk factors

\begin{tabular}{|c|c|c|c|c|}
\hline \multirow{2}{*}{ Metabolic risk factors } & \multicolumn{2}{|c|}{ Men } & \multicolumn{2}{|c|}{ Women } \\
\hline & WHtR & ABSI & WHtR & ABSI \\
\hline Waist circumference $(\mathrm{cm})$ & $0.920^{\star *}$ & $0.453^{\star \star}$ & $0.950^{\star *}$ & $0.370^{\star \star}$ \\
\hline WHR & $0.809^{\star \star}$ & $0.617^{\star \star}$ & $0.859^{\star *}$ & $0.453^{\star \star}$ \\
\hline $\mathrm{BMI}\left(\mathrm{kg} / \mathrm{m}^{2}\right)$ & $0.423^{* *}$ & $-0.294^{\star \star}$ & $0.352^{\star *}$ & $-0.259^{\star \star}$ \\
\hline Systolic BP (mmHg) & $0.217^{\star *}$ & $0.075^{* *}$ & $0.409^{* *}$ & $0.112^{\star \star}$ \\
\hline Diastolic BP (mmHg) & $0.189^{\star \star}$ & $0.056^{\star \star}$ & $0.354^{\star \star}$ & $0.084^{\star \star}$ \\
\hline Total cholesterol (mg/dL) & $0.118^{\star \star}$ & 0.012 & $0.234^{\star *}$ & $0.091^{\star \star}$ \\
\hline $\mathrm{HDL}-\mathrm{C}(\mathrm{mg} / \mathrm{dL})$ & $-0.254^{* *}$ & -0.029 & $-0.334^{\star *}$ & $-0.108^{\star \star}$ \\
\hline $\mathrm{LDL}-\mathrm{C}(\mathrm{mg} / \mathrm{dL})$ & $0.142^{\star \star}$ & 0.005 & $0.325^{\star \star}$ & $0.128^{\star \star}$ \\
\hline Triglyceride (mg/dL) & $0.237^{\star \star}$ & $0.059^{\star \star}$ & $0.354^{\star \star}$ & $0.116^{\star \star}$ \\
\hline Fasting glucose (mg/dL) & $0.170^{\star *}$ & $0.113^{\star *}$ & $0.285^{\star *}$ & $0.103^{\star *}$ \\
\hline $\mathrm{hs}-\mathrm{CRP}(\mathrm{mg} / \mathrm{dL})$ & $0.051^{*}$ & $0.070^{\star \star}$ & $0.127^{\star \star}$ & $0.086^{\star \star}$ \\
\hline HOMA-IR & $0.419^{\star \star}$ & $0.090^{\star \star}$ & $0.420^{\star *}$ & $0.076^{\star \star}$ \\
\hline
\end{tabular}

Calculated by Pearson correlation coefficient.

${ }^{*} p<0.001,{ }^{*} p<0.05$.

Abbreviations: WHtR, waist height ratio; ABSI, a body shape index; WHR, waist hip ratio; BMI, body mass index; BP, blood pressure; $\mathrm{HDL}-\mathrm{C}$, high density lipoprotein cholesterol; $\mathrm{LDL}-\mathrm{C}$, low density lipoprotein cholesterol; hs-CRP, high sensitivity C-reactive protein; HOMA-IR, homeostasis model assessment-insulin resistance. 
가 나타났다(각각 $p<0.001) . \mathrm{WHtR}$ 은 평균 $0.48 \pm 0.05$ 이었 고, 남성은 $0.49 \pm 0.04$, 여성은 $0.47 \pm 0.05$ 로 남성이 더 높았다 $(p<0.001) . \mathrm{ABSI}$ 는 평균 $0.0752 \pm 0.006$ 이었고, 남성은 $0.0763 \pm 0.004$, 여성은 $0.0739 \pm 0.007$ 로 남성이 더 높았다 $(p<$ 0.001). 수축기 혈압과 이완기 혈압은 여성보다 남성이 유의하 게 높았다(각각 $p<0.001$ ). 생화학적 변인으로 총콜레스테롤, $\mathrm{LDL}$-콜레스테롤, 중성지방, 공복혈당, $\mathrm{HbA1c}$, 인슐린, $\mathrm{HOMA}-$ $\mathrm{IR}$, 요산, hs-CRP는 여성보다 남성에서 유의하게 높았으나(각 각 $p<0.05), \mathrm{HDL}$-콜레스테롤은 남성이 여성보다 유의하게 낮 았다 $(p<0.001)$. 또한 전체 대사증후군 유병률은 $11.3 \%$ 였으 며, 남성 $13.5 \%$, 여성 $8.7 \%$ 였다. 인슐린저항성은 전체 $3.6 \%$ 를 보였으며, 남성 $4.7 \%$, 여성 $2.4 \%$ 였다(각각 $p<0.001$ ).

\section{2. 대사증후군 및 인슐린저항성 유무에 따른 WHtR과 $\mathrm{ABSI}$ 의 차이}

대사증후군 및 인슐린저항성 유무에 따른 WHtR과 ABSI의 차이를 확인한 결과는 Table 2 와 같다. 대사증후군 진단군의 $\mathrm{WHtR}$ 과 ABSI가 대사증후군으로 진단되지 않은 군보다 높게 나타났으며(각각 $p<0.001)$, 인슐린저항성이 없는 군보다 인슐 린저항성으로 진단된 군에서 $\mathrm{WHtR}$ 과 $\mathrm{ABSI}$ 가 높았다(각각 $p<$ 0.001).

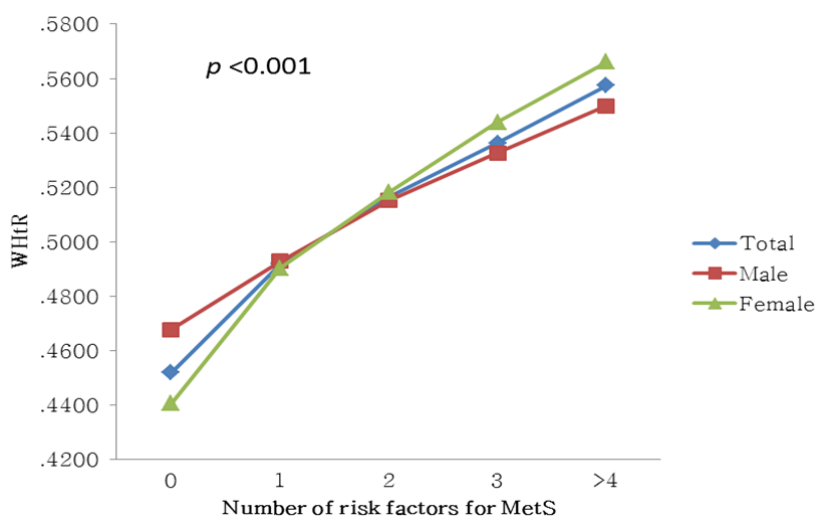

Figure 1. Comparison of WHtR differences according to the number of risk factors for MetS. WHtR increased with increasing number of risk factors for metabolic syndrome. Post-hoc test are as follows: male: MetS-0 (without metabolic syndrome components) versus MetS-1 (one component of the metabolic syndrome), $p<$ 0.001 ; MetS-1 versus MetS-2 (two components of the metabolic syndrome), $p<0.001$; MetS-2 versus MetS-3 (three components of the metabolic syndrome), $p<0.001$; MetS -3 versus MetS-4 (four or more components of the metabolic syndrome), $p<0.001$, female: MetS- 0 versus MetS-1, $p<0.001$; MetS- 1 versus MetS-2, $p<$ 0.001; MetS-2 versus MetS-3, $p<0.001$; MetS-3 versus MetS-4, $p=0.012$. Abbreviations: WHtR, waist height ratio; MetS, metabolic syndrome.

\section{WHtR 및 $\mathrm{ABS}$ 와 대사적 위험요인간의 상관관계}

성별을 나누어 $\mathrm{WHtR}$ 및 $\mathrm{ABSI}$ 와 대사적 위험요인간의 상관 관계를 확인한 결과 남성과 여성에서 $\mathrm{WHtR}$ 은 허리둘레, $\mathrm{WHR}, \mathrm{BMI}$, 수축기와 이완기 혈압, 총콜레스테롤, $\mathrm{LDL}$-콜레스 테롤, 중성지방, 공복혈당, hs-CRP, HOMA-IR과 유의한 양의 상관관계를 보였으며, $\mathrm{HDL}$-콜레스테롤과는 음의 상관관계를 보였다(각각 $p<0.05$ ). ABSI는 남성의 경우 허리둘레, WHR, 수축기와 이완기 혈압, 중성지방, 공복혈당, hs-CRP, HOMAIR과 유의한 양의 상관관계를 보였으며, BMI와는 음의 상관관 계를 보였다(각각 $p<0.001) . \mathrm{ABSI}$ 는 여성의 경우 허리둘레, $\mathrm{WHR}$, 수축기와 이완기 혈압, 총콜레스테롤, $\mathrm{LDL}$-콜레스테롤, 중성지방, 공복혈당, hs-CRP, HOMA-IR과 유의한 양의 상관 관계를 보였으며, $\mathrm{BMI}, \mathrm{HDL}$-콜레스테롤과는 음의 상관관계를 보였다(각각 $p<0.001$ ). 또한 $\mathrm{WHtR}$ 및 $\mathrm{ABSI}$ 와 대사적 위험요 인간에 상관계수를 비교한 결과 남성과 여성 모두에서 ABSI보 다 WHtR과 대사적 위험요인간의 상호 관련성이 더 높게 나타 났다(Table 3).

\section{4. 대사증후군 구성요소 개수별 WHtR과 $\mathrm{ABSI}$ 의 차이}

$\mathrm{WHtR}$ 는 남성과 여성 및 전체 대상자에서 대사증후군 구성 요소의 수가 증가할수록 직선적으로 증가하였다 $p<0.001)$ (Figure 1). ABSI는 전체 대상자에서는 대사증후군 구성요소의 개수별 $\mathrm{ABSI}$ 에는 차이가 있었으나 $(p<0.001)$, 남성과 여성을

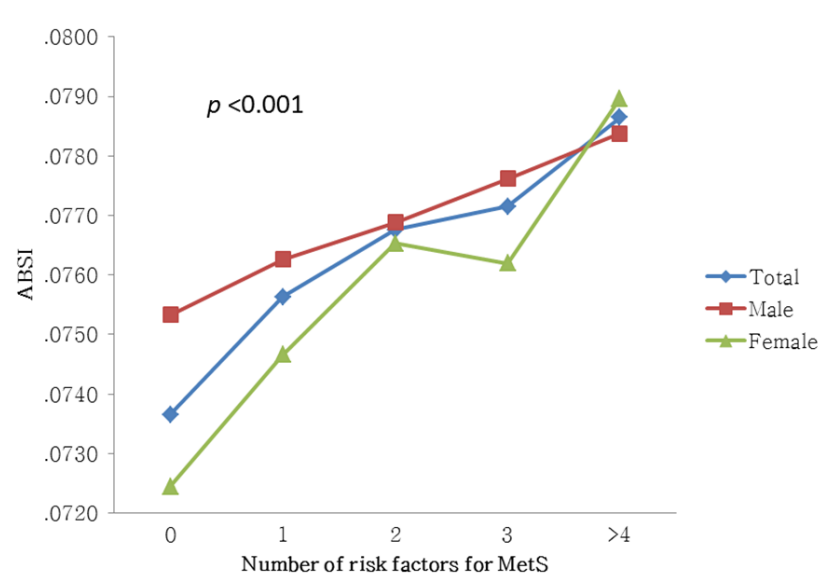

Figure 2. Comparison of $\mathrm{ABSI}$ differences according to the number of risk factors for MetS. As a result of sex classification, there was no difference in $\mathrm{ABSI}$ between two or more components of metabolic syndrome. Post-hoc test are as follows: male: MetS-0 versus MetS-1, $p<0.001$; MetS-1 versus MetS-2, $p=0.049$; MetS-2 versus MetS $-3, p=0.270$; MetS -3 versus MetS $-4, p=1.000$, female: MetS-0 versus MetS-1, $p<0.001$; MetS-1 versus MetS-2, $p=0.007$; MetS-2 versus MetS-3, $p=1.000$; MetS -3 versus MetS $-4, p=0.159$. Abbreviations: ABSI, a body shape index; MetS, metabolic syndrome. 
Table 4. Comparison of ABSI and WHtR that best predicts MetS

\begin{tabular}{|c|c|c|c|c|c|c|}
\hline & & Cutoff value & Sensitivity & Specificity & $\begin{array}{c}\text { AUC } \\
\text { (95\% confidence interval) }\end{array}$ & $p$-value \\
\hline \multirow[t]{3}{*}{ WHtR } & Total & 0.52 & $77.3 \%$ & $78.8 \%$ & $0.849(0.833 \sim 0.865)$ & $<0.001$ \\
\hline & Male & 0.52 & $73.6 \%$ & $74.4 \%$ & $0.806(0.782 \sim 0.831)$ & $<0.001$ \\
\hline & Female & 0.52 & $83.8 \%$ & $83.5 \%$ & $0.894(0.873 \sim 0.915)$ & $<0.001$ \\
\hline \multirow[t]{3}{*}{ ABSI } & Total & 0.075 & $69.0 \%$ & $58.0 \%$ & $0.676(0.653 \sim 0.700)$ & $<0.001$ \\
\hline & Male & 0.076 & $64.8 \%$ & $56.9 \%$ & $0.633(0.602 \sim 0.664)$ & $<0.001$ \\
\hline & Female & 0.076 & $62.0 \%$ & $71.8 \%$ & $0.703(0.663 \sim 0.743)$ & $<0.001$ \\
\hline \multirow[t]{3}{*}{ WC } & Total & 95.75 & $65.5 \%$ & $70.3 \%$ & $0.727(0.702 \sim 0.751)$ & $<0.001$ \\
\hline & Male & 97.75 & $62.1 \%$ & $73.7 \%$ & $0.720(0.690 \sim 0.751)$ & $<0.001$ \\
\hline & Female & 94.50 & $55.3 \%$ & $78.6 \%$ & $0.712(0.670 \sim 0.754)$ & $<0.001$ \\
\hline \multirow[t]{3}{*}{ WHR } & Total & 0.885 & $74.2 \%$ & $70.5 \%$ & $0.799(0.780 \sim 0.817)$ & $<0.001$ \\
\hline & Male & 0.895 & $78.5 \%$ & $63.2 \%$ & $0.773(0.747 \sim 0.799)$ & $<0.001$ \\
\hline & Female & 0.845 & $81.0 \%$ & $76.0 \%$ & $0.857(0.832 \sim 0.882)$ & $<0.001$ \\
\hline
\end{tabular}

Abbreviations: AUC, area under the curve; WHtR, waist height ratio; MetS, metabolic syndrome; ABSI, a body shape index; WC, waist circumference; WHR, waist hip ratio.

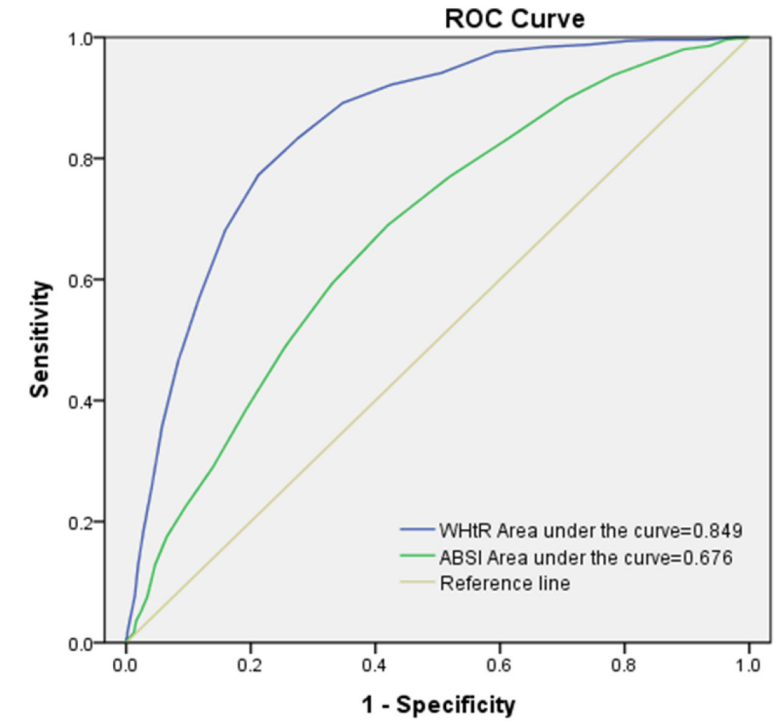

Figure 3. ROC curve of WHtR and ABSI for predicting MetS (total subjects). Abbreviations: ROC, receiver operating characteristic curve; WHtR, waist height ratio; ABSI, a body shape index; MetS, metabolic syndrome.

나누어 비교하였을 경우 남성과 여성 모두에서 대사증후군 구성 요소가 2개 이상인 경우 차이가 없는 것으로 나타났다(Figure 2).

\section{5. 대사증후군을 예측하기 위한 적정 WHtR과 $\mathrm{ABSI}$ 수준}

$\mathrm{ROC}$ 분석을 이용하여 대사증후군을 예측하기 위한 WHtR 과 $\mathrm{ABSI}$ 의 적정 기준치를 측정한 결과는 Table 4 와 같으며, Figure 3에서는 WHtR과 ABSI의 ROC 곡선을 나타냈다. 전체 대상자에서 WHtR의 AUC 값은 0.849 , 남성은 0.806 , 여성은 0.894 로 나타났다(각각 $p<0.001)$. 또한 대사증후군 예측을 위 한 전체 대상자의 WHtR 기준값은 0.52 , 민감도는 $77.3 \%$, 특이

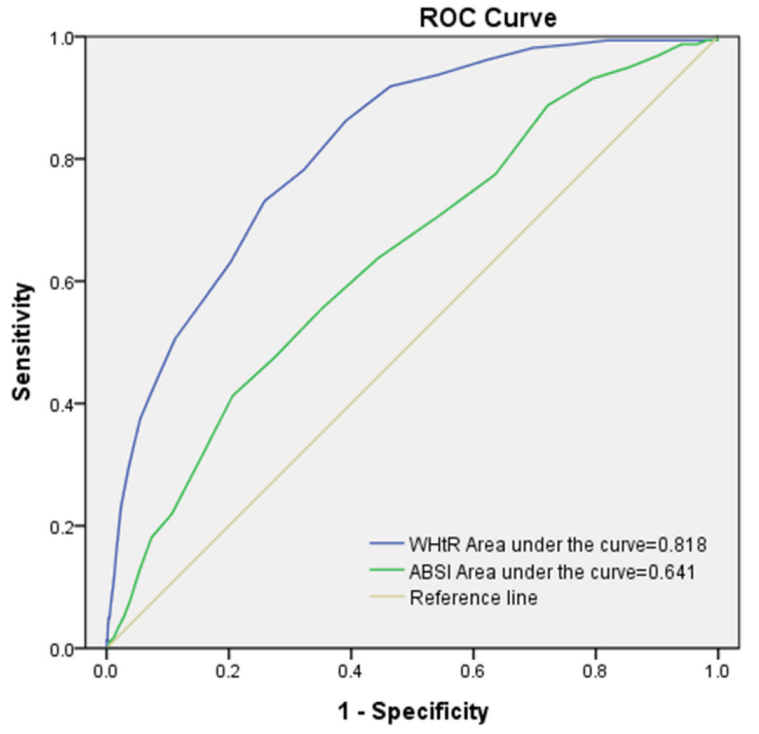

Figure 4. ROC curve of WHtR and ABSI for predicting IR (total subjects). Abbreviations: ROC, receiver operating characteristic curve; WHtR, waist height ratio; ABSI, a body shape index; IR, insulin resistance.

도는 78.8\%로 나타났다. 남성 대상자의 경우 $\mathrm{WHtR}$ 기준값은 0.52 , 민감도 $73.6 \%$, 특이도 $74.4 \%$, 여성 대상자의 $\mathrm{WHtR}$ 기준 값은 0.52 , 민감도 $83.8 \%$, 특이도 $83.5 \%$ 로 나타났다. 전체 대상 자에서 $\mathrm{ABSI}$ 의 $\mathrm{AUC}$ 값은 0.676 , 남성은 0.633 , 여성은 0.703 으로 나타났다(각각 $p<0.001$ ). 또한 대사증후군 예측을 위한 전체 대상자의 $\mathrm{ABSI}$ 기준값은 0.075 , 민감도는 $69.0 \%$, 특이도 는 $58.0 \%$ 로 나타났다. 남성 대상자의 경우 ABSI 기준값은 0.076 , 민감도 $64.8 \%$, 특이도 $56.9 \%$, 여성 대상자의 $\mathrm{ABSI}$ 기준 값은 0.076 , 민감도 $62.0 \%$, 특이도 $71.8 \%$ 로 나타났다. WHtR 은 대사증후군을 예측하는데 있어서 허리둘레, WHR보다 높은 
Table 5. Comparison of ABSI and WHtR that best predicts IR

\begin{tabular}{clccccc}
\hline \multirow{2}{*}{ WHtR } & Cutoff value & Sensitivity & Specificity & (95\% confidence interval) & $p$-value \\
& Total & 0.52 & $73.1 \%$ & $74.2 \%$ & $0.818(0.788 \sim 0.849)$ & $<0.001$ \\
& Male & 0.52 & $71.2 \%$ & $69.9 \%$ & $0.790(0.749 \sim 0.831)$ & $<0.001$ \\
& Female & 0.52 & $77.6 \%$ & $79.0 \%$ & $0.849(0.796 \sim 0.902)$ & $<0.001$ \\
ABSI & Total & 0.079 & $41.3 \%$ & $79.4 \%$ & $0.641(0.598 \sim 0.684)$ & $<0.001$ \\
& Male & 0.079 & $44.1 \%$ & $73.3 \%$ & $0.606(0.552 \sim 0.661)$ & $<0.001$ \\
& Female & 0.073 & $79.6 \%$ & $41.8 \%$ & $0.644(0.565 \sim 0.723)$ & 0.001 \\
& Total & 94.75 & $71.9 \%$ & $61.2 \%$ & $0.731(0.692 \sim 0.769)$ & $<0.001$ \\
& Male & 97.75 & $60.4 \%$ & $70.3 \%$ & $0.698(0.649 \sim 0.747)$ & $<0.001$ \\
& Female & 93.75 & $65.3 \%$ & $70.1 \%$ & $0.737(0.667 \sim 0.808)$ & $<0.001$ \\
& Total & 0.885 & $73.1 \%$ & $67.0 \%$ & $0.774(0.739 \sim 0.810)$ & $<0.001$ \\
& Male & 0.925 & $60.4 \%$ & $79.5 \%$ & $0.752(0.705 \sim 0.800)$ & $<0.001$ \\
& Female & 0.865 & $63.3 \%$ & $81.2 \%$ & $0.797(0.738 \sim 0.856)$ & $<0.001$ \\
\hline
\end{tabular}

Abbreviations: AUC, area under the curve; WHtR, waist height ratio; IR, insulin resistance; ABSI, a body shape index; WC, waist circumference; WHR, waist hip ratio.

분류 정확도를 보였으나, ABSI는 허리둘레 WHR보다 낮은 분 류 정확도를 나타냈다.

\section{6. 인슐린저항성을 예측하기 위한 적정 WHtR과 ABSI 수준}

인슐린저항성을 예측하기 위한 WHtR과 ABSI의 적정 기준 치를 측정한 결과 전체 대상자에서 WHtR의 AUC 값은 0.818, 남성은 0.790 , 여성은 0.849 로 나타났다(각각 $p<0.001$ ). 또한 인슐린저항성 예측을 위한 전체 대상자의 $\mathrm{WHtR}$ 기준값은 0.52 , 민감도는 $73.1 \%$, 특이도는 $74.2 \%$ 로 나타났다. 남성의 경 우 WHtR 기준값은 0.52 , 민감도 $71.2 \%$, 특이도 $69.9 \%$, 여성의 WHtR 기준값은 0.52 , 민감도 $77.6 \%$, 특이도 79.0\%로 나타났 다. 전체 대상자에서 $\mathrm{ABSI}$ 의 $\mathrm{AUC}$ 값은 0.641 , 남성은 0.606 , 여 성은 0.644 로 나타났다(각각 $p<0.001$ ). 또한 인슐린저항성 예 측을 위한 전체 대상자의 $\mathrm{ABSI}$ 기준값은 0.079 , 민감도는 $41.3 \%$, 특이도는 $79.4 \%$ 로 나타났다. 남성 대상자의 경우 $\mathrm{ABSI}$ 기준값은 0.079 , 민감도 $44.1 \%$, 특이도 $73.3 \%$, 여성 대상자의 $\mathrm{ABSI}$ 기준값은 0.073 , 민감도 $79.6 \%$, 특이도 $41.8 \%$ 로 나타났 다. WHtR은 인슐린저항성을 예측하는데 있어서 허리둘레, WHR보다 분류 정확도가 높았으나, ABSI는 허리둘레, WHR보 다 분류 정확도가 낮았다(Table 5, Figure 4).

\section{고 찰}

이 연구는 한국인을 대상으로 남성과 여성 모두에서 ABSI가 다른 복부비만을 나타내는 허리둘레, WHR, WHtR보다 인슐린 저항성과 대사증후군에 대한 예측력이 낮은 인자였으며, $\mathrm{WHtR}$ 은 인슐린저항성 및 대사증후군 위험 예측력이 가장 높은 지표
임을 확인하였다.

비만은 인슐린저항성 및 혈관 내피세포 기능장애와 관련이 있으며, 대사증후군 및 관상동맥질환을 포함한 심혈관계 질환 의 위험요인이다[5]. 대사증후군은 이상지질혈증, 고혈압, 고혈 당, 복부비만을 포함하는 만성 대사장애로 특히 복부비만은 대 사증후군과 밀접한 관련성을 보인다[6]. 그러나 비만은 적용하 는 진단기준이나 측정방법에 따라 평가가 달라질 수 있다. 따라 서 이러한 질환들을 예방 및 조기진단하기 위해서는 간편하고 측정이 용이한 비만관리 지표의 활용이 요구된다. 최근 복부비 만을 반영하는 비만관리 지표로 허리둘레, WHtR, WHR, ABSI 등이 대두되었다 $[8,9,26,27]$. 허리둘레는 서양인과 동양인의 신장차이로 인해 서로 다른 기준치를 적용하는데 반해 WHtR은 허리둘레를 신장으로 교정함으로써 인종, 성별, 연령에 따라서 공통적으로 적용할 수 있다고 보고된다[6].

실제로 $\mathrm{WHtR}$ 은 인슐린저항성 및 대사증후군 위험을 평가하 기 위한 선별 도구로서 민감하고 저렴하며, 쉽게 비만을 평가하 는 도구로 제안되었다[4]. 본 연구에서 $\mathrm{ROC}$ 곡선을 활용하여 $\mathrm{AUC}$ 값을 확인한 결과 WHtR은 대사증후군 및 인슐린저항성 의 예측지표로 허리둘레, WHR 및 $\mathrm{ABSI}$ 보다 높은 정확도를 보 였다. 또한 WHtR은 대사적 위험요소들과도 상관성을 보였는 데, 특히 허리둘레 및 WHR과 높은 상관성을 나타냈다.

Hadaegh 등[28]은 당뇨병을 예측하는데 허리둘레, WHR, $\mathrm{WH}$ tR 및 BMI를 포함한 중심성 비만 측정지표의 예측능력을 평가한 결과, $\mathrm{WHtR}$ 은 다른 지표들보다 제 2형 당뇨병의 발병 을 예측할 수 있는 가장 좋은 지표라고 보고하였다. 또한 아시아 인을 대상으로 WHtR이 다른 비만지표들보다 심혈관 대사질환 과 더 밀접한 관련이 있으며[29-31], 국내 연구를 통해서도 일 
반인뿐만 아니라 당뇨 전단계 환자들을 대상으로 $\mathrm{WHtR}$ 이 다른 비만지표들 보다 대사증후군을 예측하는데 유용함을 확인하였 다[6,32]. 구체적 절단값에 대한 선행연구를 보면 영국인을 대 상으로 WHtR이 0.5 이상인 경우 심혈관 대사위험요인이 높아 지는 것으로 보고되며[33], 국내에서는 $\operatorname{Kim}$ 등[6]이 당뇨병전 기 환자를 대상으로 대사증후군 진단을 위한 WHtR의 적정 기 준치를 확인한 결과 남녀 모두에서 0.53 으로 나타나 남녀 구분 없이 동일한 기준치 적용이 가능함을 보고하였다. 본 연구결과 는 대사증후군과 인슐린저항성을 예측하기 위한 WHtR의 적정 기준치는 0.52 로 나타났으며, 남녀를 구분하였을 때도 동일한 결과를 보였다. 이는 중국인을 대상으로 WHtR이 0.52 이상이 면 대사증후군으로 예측할 수 있다고 보고한 Liu 등[34]의 결과 와 일치하는 결과이다.

과다한 체지방은 체중 증가만을 의미하는 것이 아니라 비만 인에서 만성질환 유병률이 증가하는 주된 원인이다[35]. 따라 서 체중만을 고려한 비만지표를 적용하는 것이 아니라 체지방 비율을 검사하는 것이 요구된다[26]. 이러한 이유로 최근 Krakauer 등[18]은 신장, 체중, 허리둘레 및 BMI를 참조하여 새 로운 비만계측 지표인 $\mathrm{ABSI}$ 를 개발하였다. 이들은 미국성인을 대상으로 $\mathrm{ABSI}$ 가 말초지방보다 내장지방과 관련이 있으며, 체 간 지방 (trunk fat mass, TFM)과는 양의 상관관계를 제지방과 는 음의 상관관계를 보여 잠재적으로 대사장애의 좋은 예측인 자가 될 수 있다고 결론지었다[18]. 또한, ABSI와 인체측정학적 지표간의 상관성을 보고하였는데, 허리둘레와는 0.439 로 가장 높은 상관계수를 나타냈다[18].

본 연구결과 성별을 구분하여 WHtR 및 ABSI와 대사적 위험 요인간의 관련성을 확인한 결과 두 지표 모두 복부비만 지표인 허리둘레, WHR과 높은 상관성을 보였다. 이는 WHtR과 ABSI 모두 공식에 신체적 특성 중 허리둘레를 참고했기 때문이다. 한 편, WHtR은 인슐린저항성을 포함한 대사적 위험요인과 관련 성을 보인 반면, $\mathrm{ABSI}$ 는 특히 남성에서 총콜레스테롤, $\mathrm{HDL}$-콜 레스테롤, LDL-콜레스테롤과는 관련이 없는 것으로 나타났다. $\mathrm{WH} \mathrm{tR}$ 과 ABSI 두 지표와 대사적 위험요인간에 유의한 상관관 계가 나타난 경우, 상관계수를 비교한 결과 남성과 여성 모두에 서 ABSI보다 WHtR과 대사적 위험요인간의 연관성이 더 높음 을 알 수 있었다.

$\mathrm{ABSI}$ 와 건강위험간의 관계에 대해서는 논란의 여지가 있다. $\mathrm{ABSI}$ 는 대사증후군의 모든 구성요소와 관련이 있으며, $\mathrm{ABSI}$ 와 $\mathrm{BMI}$ 을 조합하여 사용하는 것은 $\mathrm{BMI}$ 단독으로 평가하는 것에 비해 낮은 $\mathrm{HDL}$-콜레스테롤, 높은 중성지방 및 높은 공복혈당 을 더 잘 평가할 수 있다고 제시된 바 있다[36]. 이란인을 대상으
로 한 또 다른 연구는 $\mathrm{ABSI}$ 가 심혈관질환 위험요인과 낮은 상관 성을 보였으며, $\mathrm{AUC}$ 에 근거하여 $\mathrm{ABSI}$ 는 심혈관질환 위험과 대 사증후군에 대한 분별력이 낮음을 보고하였다[35].

본 연구에서는 전체 대상자뿐 아니라 남녀를 분류하였을 경 우에도 ABSI는 복부비만을 반영하는 허리둘레, WHR 및 WHtR 보다 대사증후군 및 인슐린저항성의 위험을 예측하는 능력이 가장 낮게 나타나 $\mathrm{ABSI}$ 가 허리둘레나 BMI보다 우수한 대사증 후군 예측지표임을 밝힌 Duncan 등[37]의 연구내용과는 상반 된 결과를 보였다. 대사증후군 위험을 예측하기 위한 $\mathrm{ABSI}$ 의 기 준치는 남녀 모두 0.076 이었으며, 인슐린저항성 위험을 예측하 는 ABSI 기준값은 남성은 0.079 , 여성은 0.073 이었다. He 등 [38]은 중국인을 대상으로 당뇨병을 예측하는 지표로써 ABSI를 검증한 결과 당뇨환자의 평균 $\mathrm{ABSI}$ 값은 0.0757 이며, 당뇨병이 없는 성인의 평균 $\mathrm{ABSI}$ 값은 0.0737 로 나타나 당뇨환자에서 $\mathrm{ABSI}$ 치가 높다고 보고하였다. 국내에서는 ABSI의 대사증후군 및 인슐린저항성 위험을 예측하기 위한 기준치를 설정한 연구 의 부재로 본 연구에서 설정된 기준값을 비교할 수는 없으나, Behboudi-Gandevani 등[4]은 성인여성을 대상으로 인슐린 저항성 예측을 위한 ABSI 기준치는 0.078 , 대사증후군의 예측 기준치는 0.077 로 제시하였다. 그러나 이러한 불일치는 연구 방법론, 표본 크기 또는 연구 대상자의 연령이나 성별의 차이로 인해 나타나는 결과일 수 있으며, 신체조성은 생활방식이나 신 체적 발달과정 및 노화현상에 의해 변할 수 있으므로 다양한 연 령대의 대규모 추가연구가 필요하겠다. 본 연구에서는 인체계 측과 대사성 질환의 연관성에 영향을 미칠 수 있는 연구 대상자 의 생활 습관과 유전적 특성을 고려하지 않고 분석을 시행하였 다. 또한 인슐린저항성의 표준이 되는 검사법은 고인슐린혈증 정상혈당 글루코스 클램프(euglycemic hyperinsulinemic clamp)법이나 본 연구에서는 HOMA-IR을 인슐린저항성 평가 를 위한 주요 지표로 사용하였다.

결론적으로, 성인 남녀를 대상으로 $\mathrm{WHtR}$ 은 인슐린저항성 과 대사증후군을 예측하는 의미있는 지표로 나타났지만, ABSI 는 허리둘레, WHR 및 WHtR과 비교하여 인슐린저항성 및 대사 증후군 위험의 예측력이 낮은 지표였다.

\section{요 약}

WHtR과 $\mathrm{ABSI}$ 는 기존 비만지표의 단점을 보완하기 위해 개 발된 복부비만을 반영한 지표이다. 이 연구는 성인남녀를 대상 으로 $\mathrm{ABSI}$ 와 WHtR의 인슐린저항성과 대사증후군에 대한 예 측능력을 허리둘레, WHR과 비교하여 알아보고자 하였다. 이 
연구는 횡단면 조사에 기초하여 2017년 1월부터 2017년 9월 까지 경기지역 일개 종합병원에서 건강진단을 받은 20세 이상 4,395명을 대상으로 하였다. 대사증후군은 AHA/NHLBI (American Heart Association/National Heart, Lung, and Blood Institute)의 진단기준에 따라 정의하였다. 인슐린저항성은 HOMA-IR값이 3.0 이상인 경우 인슐린저항성으로 판정하였 다. WHtR 및 $\mathrm{ABSI}$ 와 대사적 위험요인간에 상관계수를 비교한 결과 남성과 여성 모두에서 $\mathrm{ABSI}$ 보다 WHtR과 대사적 위험요 인간의 상관성이 더 높았다. 대사증후군을 예측하기 위한 $\mathrm{WHtR}$ 의 $\mathrm{AUC}$ 값은 $0.849, \mathrm{ABSI}$ 의 $\mathrm{AUC}$ 값은 0.676 이었다(각 각 $p<0.001$. 인슐린저항성을 예측하기 위한 WHtR의 AUC 값 은 0.818, $\mathrm{ABSI}$ 의 $\mathrm{AUC}$ 값은 0.641 이었다(각각 $p<0.001$ ). 결 론적으로, 한국인을 대상으로 $\mathrm{ABSI}$ 가 허리둘레, WHR, WHtR 지표보다 인슐린저항성과 대사증후군에 대한 예측력이 낮은 지 표였으며, WHtR은 인슐린저항성 및 대사증후군 위험 예측력 이 가장 높은 지표임을 확인하였다.

\section{Acknowledgements: None \\ Funding: None \\ Conflict of interest: None}

\section{REFERENCES}

1. Ministry of Health and Welfare, Korea Centers for Disease Control and Prevention. Korea Health Statistics 2014: Korea National Health and Nutrition Examination Survey (KNHANES VI-2). Report. Cheongju: Korea Centers for Disease Control and Prevention; 2015.

2. Reaven GM. Role of insulin resistance in human disease (syndrome X): an expanded definition. Annu Rev Med. 1993; 44:121-131.

3. Reaven GM. Banting lecture 1988. Role of insulin resistance in human disease. Diabetes. 1988;37(12):1595-1607.

4. Behboudi-Gandevani S, Ramezani Tehrani F, Cheraghi L, Azizi F. Could "a body shape index" and "waist to height ratio" predict insulin resistance and metabolic syndrome in polycystic ovary syndrome? Eur J Obstet Gynecol Reprod Biol. 2016;205:110-114.

5. National Cholesterol Education Program (NCEP) expert panel on detection, evaluation, and treatment of high blood cholesterol in adults (Adult Treatment Panel III). Third report of the National Cholesterol Education Program (NCEP) expert panel on detection, evaluation, and treatment of high blood cholesterol in adults (Adult Treatment Panel III) final report. Circulation. 2002;106(25):3143-3421.

6. Kim JM, Back MK, Ju SH, Shin MY, Kim MJ, Park YH, et al. Validation of waist-to-height ratio for predicting metabolic syndrome in patients with prediabetes. Korean J Obes. 2015; 24(1):36-43.
7. World Health Organization. Obesity: preventing and managing the global epidemic report of a WHO Consultation (WHO Technical Report Series 894). Report. Geneva: World Health Organization; 2010.

8. Nevill AM, Stewart AD, Olds T, Holder R. Relationship between adiposity and body size reveals limitations of BMI. Am J Phys Anthropol. 2006;129(1):151-156.

9. Heymsfield SB, Scherzer R, Pietrobelli A, Lewis CE, Grunfeld C. Body mass index as a phenotypic expression of adiposity: quantitative contribution of muscularity in a population-based sample. Int J Obes (Lond). 2009;33(12):1363-1373.

10. Kang SM, Yoon JW, Ahn HY, Kim SY, Lee KH, Shin H, et al. Android fat depot is more closely associated with metabolic syndrome than abdominal visceral fat in elderly people. PLoS One. 2011;6(11):e27694.

11. de Koning L, Merchant AT, Pogue J, Anand SS. Waist circumference and waist-to-hip ratio as predictors of cardiovascular events: meta-regression analysis of prospective studies. Eur Heart J. 2007;28(7):850-856.

12. Hsieh SD, Yoshinaga H. Do people with similar waist circumference share similar health risks irrespective of height? Tohoku J Exp Med. 1999;188(1):55-60.

13. Hsieh SD, Yoshinaga H, Muto T. Waist-to-height ratio, a simple and practical index for assessing central fat distribution and metabolic risk in Japanese men and women. Int J Obes Relat Metab Disord. 2003;27(5):610-616.

14. Browning LM, Hsieh SD, Ashwell M. A systematic review of waist-to-height ratio as a screening tool for the prediction of cardiovascular disease and diabetes: 0.5 could be a suitable global boundary value. Nutr Res Rev. 2010;23(2):247-269.

15. Ashwell M, Gunn P, Gibson S. Waist-to-height ratio is a better screening tool than waist circumference and BMI for adult cardiometabolic risk factors: systematic review and meta-analysis. Obes Rev. 2012;13(3):275-286.

16. Langenberg C, Shipley MJ, Batty GD, Marmot MG. Adult socioeconomic position and the association between height and coronary heart disease mortality: findings from 33 years of follow-up in the Whitehall Study. Am J Public Health. 2005;95(4): 628-632.

17. Lin WY, Lee LT, Chen CY, Lo H, Hsia HH, Liu IL, et al. Optimal cut-off values for obesity: using simple anthropometric indices to predict cardiovascular risk factors in Taiwan. Int J Obes Relat Metab Disord. 2002;26(9):1232-1238.

18. Krakauer NY, Krakauer JC. A new body shape index predicts mortality hazard independently of body mass index. PLoS One 2012;7(7):e39504.

19. Bozorgmanesh M, Sardarinia M, Hajsheikholeslami F, Azizi F, Hadaegh F. CVD-predictive performances of "a body shape index" versus simple anthropometric measures: Tehran lipid and glucose study. Eur J Nutr. 2016;55(1):147-157.

20. Maessen MF, Eijsvogels TM, Verheggen RJ, Hopman MT, Verbeek AL, de Vegt F. Entering a new era of body indices: the feasibility of a body shape index and body roundness index to identify cardiovascular health status. PLoS One. 2014;9(9): e107212.

21. Grundy SM, Cleeman JI, Daniels SR, Donato KA, Eckel RH, Franklin BA, et al. Diagnosis and management of the metabolic 
syndrome: an American Heart Association/National Heart, Lung, and Blood Institute scientific statement: Executive Summary. Crit Pathw Cardiol. 2005;4(4):198-203.

22. World Health Organization. The Asia-Pacific Perspective: Redefining obesity and its treatment. Sydney, Australia: Health Communications Australia; 2000. p19-20.

23. Moon K, Sung SH, Chang YK, Park IK, Paek YM, Kim SG, et al. The association between Apolipoprotein E genotype and lipid profiles in healthy woman workers. J Prev Med Public Health. 2010;43(3):213-221.

24. Lee S, Choi S, Kim HJ, Chung YS, Lee KW, Lee HC, et al. Cutoff values of surrogate measures of insulin resistance for metabolic syndrome in Korean non-diabetic adults. J Korean Med Sci. 2006;21(4):695-700.

25. Swets JA. Measuring the accuracy of diagnostic systems. Science. 1988;240(4857):1285-1293.

26. Gómez-Ambrosi J, Silva C, Galofré JC, Escalada J, Santos S, Millán D, et al. Body mass index classification misses subjects with increased cardiometabolic risk factors related to elevated adiposity. Int J Obes (Lond). 2012;36(2):286-294.

27. Bray GA, Smith SR, de Jonge L, Xie H, Rood J, Martin CK, et al. Effect of dietary protein content on weight gain, energy expenditure, and body composition during overeating: a randomized controlled trial. JAMA. 2012;307(1):47-55.

28. Hadaegh F, Shafiee G, Azizi F. Anthropometric predictors of incident type 2 diabetes mellitus in Iranian women. Ann Saudi Med. 2009;29(3):194-200.

29. Hsieh SD, Yoshinaga H. Waist/height ratio as a simple and useful predictor of coronary heart disease risk factors in women. Intern Med. 1995;34(12):1147-1152.

30. Hsieh SD, Yoshinaga H. Abdominal fat distribution and coronary heart disease risk factors in men-waist/height ratio as a simple and useful predictor. Int J Obes Relat Metab Disord. 1995;19(8):585-589.

31. Lee JS, Aoki K, Kawakubo K, Gunji A. A study on indices of body fat distribution for screening for obesity. Sangyo Eiseigaku Zasshi. 1995;37(1):9-18.

32. Shin KA, Hong SB, Shin KS. Body adiposity index and metabolic syndrome risk factors in Korean adults: a comparison with body mass index and other parameters. Biomed Sci Letters. 2017;23(2):57-63.

33. Ashwell M, Gibson S. Waist-to-height ratio as an indicator of 'early health risk': simpler and more predictive than using a 'matrix' based on BMI and waist circumference. BMJ Open. 2016;6(3):e010159.

34. Liu L, Ping Z, Li L, Yang Y, Li C, Zhang M. Power and the cutoff value of waist-to-height ratio predicting metabolism syndrome. Wei Sheng Yan Jiu. 2012;41(6):992-996.

35. Haghighatdoost F, Sarrafzadegan N, Mohammadifard N, Asgary S, Boshtam M, Azadbakht L. Assessing body shape index as a risk predictor for cardiovascular diseases and metabolic syndrome among Iranian adults. Nutrition. 2014;30(6):636-644.

36. Bertoli S, Leone A, Krakauer NY, Bedogni G, Vanzulli A, Redaelli VI, et al. Association of Body Shape Index (ABSI) with cardio-metabolic risk factors: A cross-sectional study of 6081 Caucasian adults. PLoS One. 2017;12(9):e0185013.

37. Duncan MJ, Mota J, Vale S, Santos MP, Ribeiro JC. Associations between body mass index, waist circumference and body shape index with resting blood pressure in Portuguese adolescents. Ann Hum Biol. 2013;40(2):163-167.

38. He S, Chen X. Could the new body shape index predict the new onset of diabetes mellitus in the Chinese population? PLoS One. 2013;8(1):e50573. 